\title{
Building Vicarious Bridges through Colour Workshops for Pupils with Visual Impairment
}

\author{
By Filomena Agrillo* \\ Paola Aiello ${ }^{\dagger}$ \\ Iolanda Zollo \\ Erika Marie Pace ${ }^{+}$ \\ Maurizio Sibilio
}

The inclusion of pupils with visual impairment, within Italian mainstream schools, is an area of interest for the field of special education that is involved in identifying the most effective teaching strategies to promote the teaching-learning process. The perceptive difficulties that the pupils with visual impairment encounter in the first step of development can be a significant obstacle to learning and to the development of representative thinking. For this reason, it is fundamental that the teaching style adopted is oriented to promote learning through strategies that exploit the natural vicarious activity of the brain. With this aim, the present paper describes the potential of a hands-on activity with high inclusive value, which is based on a theoretical framework, that brings together contributions from different scientific domains and which, from an interdisciplinary perspective, explores the concept of "vicariance" as proposed by the physiologist of perception Alain Berthoz.

Keywords: simplexity, special education, vicariance, visual impairment, workshops.

\section{The Inclusion of Pupils with Visual Impairment in Italy: A Brief Historical Overview}

In Italy, between the late 1800s and the beginning of the 1900s various hospices, respite care houses and institutes managed by municipalities and private entities were set up (Law.17 July 1890, n. 6972). Their aim was to guarantee health and social assistance to children with visual and hearing impairment, but more generally to all the disabled (Pavone, 2014). In the early 1900s, however, the studies conducted by Maria Montessori and Augusto Romagnoli gave rise to the debate on the possibility of educating disabled persons. This led to a real educational reform in which the Italian State undertook the responsibility to educate the disabled (R.D. 5 February 1928, n.577). This reform brought about significant educational interventions for people with sensory impairment. Worth mentioning are the R.D. 30 December 1923, n. 2841, and the R.D. 31 December

\footnotetext{
* PhD Student in Didactics, Inclusive Education and Technology, University of Salerno, Italy.

${ }^{\dagger}$ Associate Professor in Special Pedagogy and Didactics, University of Salerno, Italy.

${ }^{\star}$ PhD Student in Didactics, Inclusive Education and Technology, University of Salerno, Italy

${ }^{+} \mathrm{PhD}$ Student in Didactics, Inclusive Education and Technology, University of Salerno, Italy.

- Full Professor in Special Pedagogy and Didactics, University of Salerno, Italy.
} 
1923, n.3126 which in Article 1 declared that pupils with hearing and/or visual impairment who did not present any type of irregularity or weirdness that could hinder their presence in special schools, were to attend school. Moreover, the statutes of these schools had to claim that their exclusive aims were prevalently to educate and instruct rather than to offer assistance. The school curriculum had to be the same as that implemented in mainstream schools. In addition, however, special schools had to include a differentiated part that gave importance to sensory education, music, singing, rhythm and physical education, practical activities such as manual work, gardening and care of the classroom. In particular, schools were to give a lot of importance to aesthetic education (O.M. 27 June 1924; Ceppi, 1969, p.54). On the basis of this reform special schools proliferated throughout the Italian territory (Alliegrio, 1991) guaranteeing special education to pupils with hearing and visual impairment until the early 70 s when Law $118 / 1971$ was enacted. This Law, in fact, brought about another radical change in the system, opening the doors of mainstream schools to pupils who did not present a serious disability or physical impairment. More precisely, this right was extended to children with sensory impairment in 1976, giving their parents the possibility to choose whether to send their children to mainstream or special schools (Law 360, 1976). The right to education, already enshrined in the Italian Constitution in 1948 (art. 3; art. 34, art. 38), was further guaranteed with the abolishment of special schools (Law 517/77) and a new interpretation of the educational system, viewed as a public service open to all and based on the principle of equality. For handicapped pupils, and hence also for pupils with sensory impairment, the school was expected to integrate students thanks to the provision of specialised teachers (art. 2).

These educational reforms can be considered as the first steps towards a culturally-shared type of educational model which promoted the integration of students with disability, and may have paved the way to a major acceptance of the provisions in Law 104/92. This law perceived integration within an ecological-systemic perspective while the general principles were human rights, social integration and assistance of handicapped people in all aspects of life, including education. As regards the latter policy the law stated that "the objective of school integration is the development of a handicapped person's potential to learn, communicate, build relationships and socialize" [our translation]. In fact, as stated in Article 12 Par. 3 of the same Law, all spheres of life are interconnected with each other and the school, as a formal and institutional entity, must ensure that the achievement of educational goals is not hindered by learning difficulties arising from a disability.

Such principles are substantiated on an international level, within the United Nations Convention on the Rights of Persons with Disabilities (13/12/2006), ratified in Italy with Law 18 dated on the 3rd of March 2009. In accordance with Law 104/92 and in line with the UN Convention, the main purpose of Law 18 was to promote the full integration of people with disabilities (article 3 ). It acknowledged that the concept of disability is constantly evolving because it is the result of the interaction between the person with disability and environmental and behavioural barriers that are not conducive to the effective 
social participation and the exercise of personal and social activities. These barriers represent a troubling and problematic element for nations as they inhibit the enjoyment of the inviolable human rights that ensure equality in society.

As indicated by the United Nations (2006), overcoming these barriers can and must take place through the adoption of an inclusive educational system that enhances the pupils' potential by modifying the environment to satisfy the needs of each and every student and by offering personalised support in environments that maximise academic and social development, consistent with the goals of full inclusion (art. 24, paragraph 2, letter e). To this end, the United Nations suggested that schools adopt teaching methodologies and strategies that take into account: (a) the learning style of each student, (b) alternative means of communication, (c) educational support for pupils which can be provided either by specialised teachers or peers, (d) the right to lifelong learning during the entire span of life, and (e) lifelong guidance.

As claimed in the Ministerial Decree dated 27 December 2012, "the principles underpinning the Italian school-integration model [...] have contributed to making the Italian educational system the setting for knowledge, development and socialisation of all students, highlighting inclusive aspects rather than selective ones" (p. 1) [our translation]. Since 2012, having endorsed a fully inclusive model, the spectrum of special educational needs has been broadened. This now includes needs arising from socio-economic disadvantage, specific learning difficulties, and problems deriving from cultural and linguistic differences, among others. This means offering differentiated and individualised instruction underpinned by a bio-psycho-social model that perceives the individual holistically and tends to give value to the potential of the individual rather than concentrating on deficits. Notwithstanding the evolution of cultural values and the principles endorsed by these norms, the Unione Italiana Ciechi (UIC) [Italian Blind Union] and the European Blind Union (EBU), in the proceedings of the first international conference on education of the blind and visually impaired (UIC, EBU, 2000) criticised the way the system was implemented. They claimed that the transition from special schools to mainstream schools was so fast that it did not allow enough time for schools to deeply reflect on their work and on the task conferred to them to provide an authentic educational process aimed at enhancing the full potential of each and every student (UIC, EBU, 2000, p.8).

Numerous are the difficulties faced by persons with visual impairment in their everyday lives and these may affect their participation in education and sport, the use of technology and access to information ${ }^{1}$, their autonomy and adaptation to urban and rural environments. These are only some of the needs the school has to take into consideration to guarantee their full inclusion. Research in the field has highlighted that the main learning difficulties encountered by pupils with visual impairment are not only linked to the difficulties in perceptive organisation but especially to the difficulty in adapting to the environment and the teaching practices used (Ceppi, 1969; Alliegro, 1991; Brambring, 2004;

\footnotetext{
${ }^{1}$ For further information visit http://bit.ly/2u3JfXy.
} 
Caldin, 2006; Cottini, 2008; Gargiulo, 2005; Gargiulo \& Dadone, 2009; Sibilio 2003; Perla 2013). The school is thus requested to rethink its organisational system, its tools, methods, and teaching strategies (Caldin \& Argiropoulos, 2010) to meet the pupils' needs, cognitive and learning styles; not only of the visuallyimpaired but of all pupils irrespective of their ability. In order to achieve such an ambitious aim, teachers need to be able to organise their teaching in a flexible manner. This entails "facilitating the mechanisms of decisional processes, allowing the adaptation to the environment, anticipating and facing transition and change positively, deciphering and coping with the complexities brought about by the social and cultural dynamics [...] through an array of flexible teaching strategies that are open to change" (Sibilio, 2015, pp. 331-332) [our translation].

For this reason, teaching should be oriented towards promoting learning through strategies that avail of the natural vicariant activity of the brain. In fact, through the use of the visually-impaired pupils' sensory vicariances as a teaching strategy and resource, the pupils' diverse abilities are capitalised. Moreover, the in-depth studies on sensory substitution systems (Cottini, 2008), or sensory vicariances (Berthoz, 2015), and the concept of inter and transdisciplinary vicariances (Berthoz, 2015) are fundamental for promoting the acquisition of metacognitive competencies necessary for the pupils' school performance. This will be further outlined in the next sections of the article.

\section{Brain Plasticity and Vicariance}

The concept of "vicariance" is a broad and multifaceted concept to which different scientific domains, often distinct from each other, refer to describe the mechanisms, systems, processes, operations, and devices within a specific field. Alain Berthoz (2015), physiologist of perception of the College de France, provided an interesting overview of the meanings that have been attributed to the concept of vicariance over time and within different scientific domains. The definitions summarised in Table 1 below, show that the concept of vicariance has a shared meaning between different scientific fields that is the "substitution of a process with another process that leads to the same result" (Berthoz, 2015, p.VII). 
Table 1. The Concept of Vicariance in the Different Scientific Domains

\begin{tabular}{|l|l|}
\hline $\begin{array}{l}\text { Scientific } \\
\text { Domain }\end{array}$ & \begin{tabular}{l}
\multicolumn{1}{c|}{ Definition of Vicariance } \\
\hline Biology
\end{tabular} \\
\hline Geology & $\begin{array}{l}\text { Vicarious Emphysema: } \\
\text { appears in a lung, or its part, when the contralateral organ, or } \\
\text { a lobe of the former, functions inadequately }\end{array}$ \\
\hline Psychology & $\begin{array}{l}\text { Biogeographical vicariance: } \\
\text { a new variety of species produced due to continental drift; } \\
\text { Ecological Vicariance: } \\
\text { the evolution of species induced by climate change }\end{array}$ \\
\hline Ethiology & $\begin{array}{l}\text { Functional Vicariance: } \\
\text { Reciprocal substitution of functions }\end{array}$ \\
& $\begin{array}{l}\text { Vicariance: } \\
\text { construction of one's world and giving meaning to things on } \\
\text { the basis of one's competences and the environment in which } \\
\text { he operates }\end{array}$ \\
\hline
\end{tabular}

Source: The information summarized in this table is based on the definitions provided in Berthoz 2015, pp. XII-XIV, 9-14.

The dialogue between educational sciences and the natural sciences paved the way to new areas of study in the field of education such as bio education (Frauenfelder \& Santoianni, 2002), enactivism (Rossi, 2011) and neurodidactics (Rivoltella, 2012). This, in turn, led to an in-depth reflection on the possible educational implications of the empirical evidence deriving from the hard sciences (Sibilio, 2012), more specifically from neurobiological studies on neuronal plasticity - the capacity of the nervous system to modify the synaptic connections, and hence its structure and its functions, on the basis of the events it is involved in. Within these studies, learning is configured as an experience that can influence this process of plasticity since it promotes the development of dendrites in the brain cells and the increase in brain connections (Robertson, 2011).

Initially this theory - learning as a form of adaptation - has focused its attention on the field of intelligence. In the studies that led to the theory of genetic epistemology, Piaget (1972) considers intelligence as a form of adaptation since development occurs through a series of stages, each of which involves a substantial modification in brain structure, that determine the evolution from the sensorimotor stage to the formal operational stage (Piaget, 1981). According to the French psychologist, this adaptive-evolutionary process takes place through two complementary processes: assimilation and accommodation. In order to explain how events affect development, Piaget uses the concept of "schema" understood as the organisation of adaptive action; in other words, as a particular cognitive structure (Piaget, 1981) applied to objects, ideas, etc. Assimilation is the process of incorporating new information obtained using already-owned schemes and cognitive structures. This process, which leads to the natural imbalance of the already-owned schemes, finds its balance through accommodation, which entails adapting the pre-existing schemes to accommodate the new ones (Piaget, 1981).

Nowadays thanks to neuroimaging, the stages Piaget had observed through 
behaviour analysis can be studied on a neurobiological level through brain mapping. This allows to identify and graphically display areas allocated for different mental functions but also to understand what happens when certain areas seem to stop functioning due to organ damage, among other reasons. As Doidge (2015) explains, a damaged brain can often reorganise itself in a way that, when a part stops functioning, another substitutes it. When brain cells die, they are replaced by others. Indeed, many circuits and even fundamental reflexes, which we think are wired, are not at all. This concept, which contrasts the idea that within the brain each component performs a specific mental function and its position is genetically-predetermined (Doidge, 2015), is empirically demonstrated by neuroscientific studies conducted with visuallyimpaired individuals.

While conducting research for the construction of a tactile-vision instrument, Bach-y-Rita (1969; Bach-y-Rita, Collins, Saunders, White, \& Scadden, 1983) discovered that the senses can be involved in a process which he defined sensory substitution. This process is triggered when one of the senses is damaged. In the case of visual impairment, touch receptors in the skin can replace the retina, since both are bi-dimensional structures covered with sensory receptors, which allow the creation of images on their surface (Doidge, 2015). Such a substitution inevitably leads to a modification in the structure responsible for sensory perception as the brain, in the absence of vision, must decode the tactile sensations, interpret them and convert them into images. What enables this process is the sensory-perceptive reorganisation. The brain learns something new and adapts itself to signals of a new type, thus changing its structure.

Moreover, these studies led Bach-y-Rita (1969; Bach-y-Rita, Collins, Saunders, White, \& Scadden, 1983) to hypothesise the polysensoriality of the various areas of the brain. This refers to the ability of the sensory regions to elaborate data originating from more than one sense.

Among the noteworthy studies conducted on how the brain learns new skills, were those conducted by Pascual-Leone (Pascual-Leone \& Torres, 1993; Pascual, Wassermann, Sadato, \& Hallett, 1995; Pascual-Leone, Hamilton, Tormos, Keenan, \& Catala, 1999) using the Transcranical Magnetic Stimulation (TMS) to map the brain of blind individuals who were learning to read Braille.

Those who read Braille slide their index finger on the raised dots, so the reading activity takes the form of motor activity through which the position of the points in space are perceived and discriminated (sensory activity). When Pascual-Leone used TMS to map the motor cortex, he found that the cerebral area responsible for the index finger was broader than those of the other fingers and of those who are not able to read Braille. These results were the first to confirm that when human beings learn new abilities, change takes place in the brain. However, the most interesting discovery made by Pascual-Leone (Pascual-Leone \& Torres, 1993; Pascual, Wassermann, Sadato, \& Hallett, 1995; Pascual-Leone, Hamilton, Tormos, Keenan, \& Catala, 1999) is that related to vicarious bridges, which the damaged areas in the brain create with the functioning areas.

In order to verify if the tactile reading skills in blind people were indeed 
favoured only by the motor cortex or even by other brain regions such as the visual cortex, Pascual-Leone introduced a virtual lesion to the visual cortex. On introducing this lesion, the blind people were unable to read or to perceive Braille with their index finger. This meant that although not receiving visual stimuli, the visual cortex is still involved in the processing of the tactile input. When applying this same methodology to a sample of people with no visual impairment and who could read Braille, no effect was recorded. This meant that people could read Braille despite the lesion. This indicated that a cerebral plastic reorganization, where neurons responsible for vision contribute to other brain activities, occurs only in blind readers.

Pierre Oléron (1963; 1978; 1981; Fraisse \& Oleron, 1952), in his studies conducted to analyse the functioning of the auditory system, also defined this process as sensory substitution and claimed that this regulatory mechanism of the perceptual system is identical for all senses and for all people: all that blind people are able to acquire through the use of different senses other than sight, can also be acquired by sighted people. To curb this process in sighted people is the visual dominance (Le Boulch, 1979) for which the auditory, tactile, kinesthetic, olfactory information is largely excluded from the conscious processing of information.

\section{Simplexity, Vicariance and Teaching}

The process of sensory substitution is also present in the studies of the French physiologist Alain Berthoz $(2009 ; 2015)$ as one of the simplex properties of living organisms needed to find solutions in order to decipher and face complexity. "Simplexity is complexity decoded, so to speak, because it is based on a rich combination of simple rules" (Berthoz, 2009 p. XI) that characterize the complex adaptive systems and, therefore, even the human brain.

This theory provides an innovative interpretative key to understanding sensory re-modulation in cases of visual impairment. As previously outlined, different areas of the brain are responsible for specific functions. This separation of functions leads to a temporal discrimination of the different sensory functions even if they cooperate in a modular manner. In the presence of visual impairment, the cerebral area responsible for sight, not being able to fulfill that function, cooperates with the other areas to process sensory data originating from other senses (tactile, auditory, olfactory, etc). Such cooperation is a form of flexibility and adaptation to change since the brain restructures itself in a flexible manner on the basis of this dysfunction, finding solutions to and compensating for the problem of sensory perception and the construction of images through detours and vicariant strategies. Basically, what happens is that the brain implements a real detour which "appears complex [...] but that actually results in simpler and a more efficient control of the system" (Berthoz, 2009, p. 18). This apparent complexity is "resolved" through vicariance, i.e. the replacement of "a defective system with another element [...], the brain's way of creating a solution that replaces the failed system" (Berthoz, 2009, p.33). 
Berthoz refers to two types of Vicariance:

- Functional Vicariance understood as the "replacement of a mechanism, or process, by another mechanism or process that can lead to the same result" (Berthoz, 2015, p.5) [our translation], meaning that there is the possibility of carrying out the same task or reaching the same goal in many different ways;

- Vicariance of Use understood as the " ability of living organisms to take advantage of the surrounding world in a very different way, depending on the objectives and limits of their Umwelt ${ }^{21 "}$ (Berthoz, 2015, p.9) [our translation], which means that an object is used for situations other than those which it was designed or created for.

In the field of education, vicariance represents one of the adaptation tools (Berthoz, 2015) which teachers can use to make their teaching flexible in view of the differences among their learners, thus favoring the development of their potential (Sibilio , 2014). It can also be considered as a learning tool (Berthoz, 2015) because every pupil has his/her own cognitive and learning style in relation to his/her Umwelt (visual, auditory, kinesthetic, etc.) (Sibilio, 2014). The challenge in the teaching-learning process is to adapt the teaching to the pupils in a personalised manner so that in light of their potential, characteristics and inclinations they can perform well in school.

\section{The Development of Representative Thinking of Pupils with Visual Impairment through Colour Workshops}

The perceptual difficulties that an individual with visual impairment encounters in the early stages of development may be a potential barrier to learning and the development of representational thought which starts developing during the preoperational stage (2 to 6/7 years) (Piaget, 1972). This form of thought is characterised by the capacity to carry out formal operations, to break away from concrete reality and perform complex operations with ideas. In the presence of visual impairment, the transition from concrete thought (closely linked to the reality at hand) to a representative type of thinking (linked to mental images of reality that the child constructs on the basis of his/her experience), may not be so simple. In addition, it can be hampered by the difficulty in building a mental picture of abstract concepts, symbols and experiences. This is the case of colour. In the National Curriculum Guidelines for nursery schools, colour represents a fundamental experiential field for children, useful to introduce them to aesthetic skills and to experience emotions, imagination and creativity

\footnotetext{
2 Jakob von Uexküll (1982) is known for his studies on how living organisms subjectively perceive and interpret their environments. The key notion of his theory is "Umwelt" which is usually translated as subjective universe, although in German it simply means 'environment'. Most ecologists assume that all organisms in the ecosystem share the same environment, but Uexküll thought that organisms may have different Umwelts even if they live in the same place.
} 
(MIUR, Indicazioni Nazionali, 2012).

\section{Objective of the Activity}

The objective of "Building vicarious bridges through colour workshops" is that of favouring the construction of the mental image of colour in visuallyimpaired children through an innovative and flexible approach based on the principle of vicariance. Moreover, based on the premise that in Italy all students irrespective of their ability are taught in mainstream schools, the workshop is aimed at involving all students to experiment the use of colour through all their senses.

\section{Methodology}

The experimentation of this teaching strategy envisages the following 4 main phases:

1. Identification of schools within the Region of Campania where visuallyimpaired pupils are enrolled;

2. Meeting with the teachers involved to identify the pupils' needs and to brief them on the workshop to be conducted;

3. Delivery of the "Building vicarious bridges through colour workshops";

a. Phase 1: pupils experiment with powdered pigments of the primary colours using touch and olfactory senses.

b. Phase 2: pupils mix the powdered pigments of the primary colours with gel to be used in the third phase. Using their olfactory sense children will observe the various perceptions that the colours stimulate to be able to discriminate them.

c. Phase 3: in this phase pupils can experiment with colour using their tactile senses. Manipulating colour, they will observe the difference in fluidity, density and other tactile characteristics such as rough and smooth.

d. Phase 4: With a paintbrush, pupils will experiment the sound and the vibration different colours emit when they come in contact with a rough canvas.

4. Evaluation of the workshop.

The sample will consist of 20 pupils, three of whom are visually impaired. The age of the pupils will be between 7 and 8 years. The rationale behind the choice of this age group is that at this developmental stage children have developed enough lexis to be able to describe colours through the sensations they perceive. This experience lasts a total of 9 hours divided into three workshops. 


\section{Expected Results}

All pupils will learn to recognise colours and construct a mental representation of it that goes beyond the sense of sight. This experience will make pupils more aware of the value and use of all their senses, thus promoting flexibility in approaching different life experiences. Moreover, the workshop will provide sighted children with a concrete experience that impairment can be overcome by looking for vicarious trajectories. Data will be collected using video recordings that will then be analysed for verbal behaviour and to extrapolate information regarding the feelings expressed throughout the activity. This will provide insight for the construction of an observation checklist to be used with other groups of students.

\section{Conclusions}

The insights provided by neuroscience about the vicarious nature of brain activity suggest that the knowledge and understanding of the world around us can occur in many different ways and according to specific characteristics of each human being. Respecting individual differences and planning learning activities that enhance these differences means pursuing inclusive objectives. The "Building bridges through vicarious colour workshop" adopts the principle that the senses are the tools, the means through which individuals reach the goals. Being deprived of a sense such as sight does not impose limits and restrictions if there is awareness of the fact that the same objectives can be reached in many different ways. Experiencing colour for the visually-impaired can in no way be the same: the blind will never see through the sense of sight. Yet they can see through touch, hearing and smell.

\section{References}

Alliegrio, M. (1991). Privo della vista. Uomo e lavoratore. Cenni di tiflopedagogia e didattica differenziata [Visually-impaired. Man and worker. Tiflopedagogy and differentiated instruction]. Cagliari: COEDISAR.

Bach-y-Rita, P. 1972. Brain mechanisms in sensory substitution. Academic Press.

Bach-y-Rita, P. (1983). Recupero funzionale [Functional recovery]. Cosenza: Brenner Ed.

Bach-y-Rita, P., Collins, C.C., Saunders, F.A., White, B., Scadden, L. (1969). Vision substitution by tactile image projection. Nature 221(5184), 963-964.

Berthoz, A. (2009). Simplexity: simplifying principles of a complex world. USA: Yale University

Berthoz, A. (2015). La Vicarianza. Il nostro cervello creatore di mondi [Vicariance. Our brain creator of worlds]. Torino: Codice Edizioni

Brambring, M. (2004). Lo sviluppo nei bambini non vedenti. Osservazione e intervento precoce [The development of visually-impaired children. Observation and early intervention]. Milano: FrancoAngeli. 
Caldin, R. (2006). Percorsi educativi nella disabilità visiva: identità, famiglia e integrazione scolastica e sociale [Educational routes in visual impairment: identity, family and school and social integration]. Trento: Edizioni Erickson.

Caldin, R., Argiropoulos, D. (2010). Genitori migranti e figli con disabilità Le rappresentazioni dei professionisti e le percezioni delle famiglie [Migrant parents and children with disability. The perceptions of professionals and families]. Ascicolo, 2(5), 75.

Ceppi, E. (1969). I minorati della vista [The visually-impaired]. Roma: armando editore.

Cottini, L. 2008. Per una didattica speciale di qualità: dalla conoscenza del deficit all'intervento inclusivo. [Quality in special education: from knowing the impairment to implementing inclusive interventions]. Perugia: Morlacchi Editore.

Ministerial Decree 27 December (2012). Strumenti d'intervento per alunni con bisogni educativi speciali e organizzazione territoriale per l'inclusione scolastica [Intervention tools for pupils with special educational needs and territorial organization for school inclusion].

Doidge, N. (2015). Le Guarigioni del Cervello. Le nuove strade della neuroplasticità: terapie rivoluzionarie che curano il nostro cervello [Healing of the brain. The new routes of neuroplasticity: revolutionary therapies that cure our brain]. Milano: Ponte alle Grazie.

Fraisse, P., \& Oléron, P. (1952). La perception [Perception]. L'année psychologique, 52(2), 520-533.

Frauenfelder, E., \& Santoianni, F. (2002). Le scienze bioeducative. Prospettive di ricerca [Bioeducation. Research perspectives]. Napoli: Liguori editore.

Gargiulo, M.L. (2005). Il bambino con deficit visivo. Comprenderlo per aiutarlo. Guida per genitori, educatori, riabilitatori [The child with visual impairment Understanding him to help. A guide for parents, educators and therapists]. Milano: Franco Angeli.

Gargiulo, M.L., Dadone, V. 2009. Crescere toccando. Aiutare il bambino con deficit visivo attraverso il gioco sonoro. Uno strumento per educatori e terapisti. [Growing up through touch. Helping the child with visual impairment through an auditory game. A tool for educators and therapists]. Milano: Franco Angeli.

Le Boulch, J. (1979). Educare con il movimento [Educating through movement]. Roma: Armando Editore.

Law 17 July 1890, N. 6972 (Gazzetta Ufficiale 22 luglio 1890, n. 171). Norme sulle istituzioni pubbliche di assistenza e beneficenza [Standards on public service and charitable institutions].

MIUR (2012). Indicazioni nazionali per il curricolo della scuola dell'infanzia e del primo ciclo d'istruzione [National guidelines for the curriculum of the childhood school and the first cycle of education].

Oléron, P. (1963). L'intelligence [Intelligence]. Presses universitaires de France.

Oléron, P. (1978). Le langage gestuel des sourds: syntaxe et communication [Deaf language: syntax and communication]. No. 43, Éditions du Centre national de la recherche scientifique.

Oléron, P. (1981). Savoirs et savoir-faire psychologiques chez l'enfant [Psychological knowledge and know-how on children]. Vol. 100, Editions Mardaga.

Ministerial Order (Ordinanza Ministeriale, O.M.), 27 June 1924. Istruzione elementare dei ciechi [Primary education of the blind].

Pascual, A., Wassermann, E. M., Sadato, N., Hallett, M. (1995). The role of reading activity on the modulation of motor cortical outputs to the reading hand in Braille readers. Annals of Neurology, 38(6), 910-915.

Pascual-Leone, A., Hamilton, R., Tormos, J.M., Keenan, J.P., Catala, M.D. (1999). Neuroplasticity in the adjustment to blindness. Neuronal plasticity: Building a 
bridge from the laboratory to the clinic (pp. 93-108). Berlin: Springer Berlin Heidelberg.

Pascual-Leone, A., Torres, F. (1993). Plasticity of the sensorimotor cortex representation of the reading finger in Braille readers. Brain, 116(1), 39-52.

Pavone, M. (2014). L'inclusione educativa. Indicazioni pedagogiche per la disabilità [Educational inclusion. Pedagogical indications for disability]. Milano: Mondadori

Perla, L. (2013). Per una didattica dell'inclusione [For an inclusive education]. Lecce: Pensa Editore.

Piaget, J. (1972). Intellectual evolution from adolescence to adulthood. Human development, 15(1), 1-12.

Piaget, J., (1981). L'equilibrazione delle strutture cognitive: problema centrale dello sviluppo [Balancing cognitive structures: central development problem]. Torino: Boringhieri.

Royal decree (Regio Decreto, R.D.), 31 December 1923, n.3126, Disposizioni sull' obbligo scolastico [Provisions on school obligations].

Royal decree (Regio Decreto, R.D.), 30 December 1923, n. 2841, Reform of the Law of July 17,1890 , no. 6972 , on public service and charitable institutions

Royal decree (Regio Decreto, R.D.), February 5, 1928, no. 577 (OJ No 095 of 23/04/1928). Approval of the Single Text of Laws and Legal Standards, Existing in Virtue of Art, 1, No. 3, of the Law of January 31, 1926, No. 100, on Primary, Post-Elemental, and On Its Integration Works. (Published in Official Gazette No. 95 of April 23, 1928).

Rivoltella, P.C. (2012). Neurodidattica. Insegnare al cervello che apprende [Neurodidactics. Teaching the learning brain]. Milano: Raffaello Cortina Editore

Robertson, I.H., (2011). Il cervello plastico [The plastic brain]. Corriere della Sera.

Rossi, P.G. (2011). Didattica enattiva. Complessità, teorie dell'azione, professionalità docente [Enactive Didactics. Complexity, theories of action, the teaching profession]. Milano: Franco Angeli Editore.

Sibilio, M. (2003). Le abilità diverse. Percorsi didattici di attività motorie per soggetti diversamente abili [Diverse abilities. Teaching strategies in physical education for students with diverse abilities]. Napoli: Esselibri.

Sibilio, M. (2012). Corpo e cognizione nella didattica. L'agire didattico. Manuale per l'insegnante [Teaching: A teachers' manual] (pp. 329-347). Brescia: La Scuola.

Sibilio, M. (2014). La didattica semplessa [Simplex didactics]. Napoli: Liguori Editore.

Sibilio, M. (2015). La funzione orientativa della didattica semplessa [The function of simplex didactics in guidance]. Pedagogia Oggi, vol. 1(2015), 327-334.

UIC, EBU, (2000). Il ruolo delle associazioni e delle famiglie per il miglioramento delle condizioni dell'istruzione dei ciechi e degli ipovedenti [The role of associations and families to improve the education conditions of the blind and visually impaired people. I International EBU Conference on Education]. $1^{\text {st }}$ EBU International Conference on Education, July 19-23, Padua, Italy. 